\title{
Bcl-2 Expression in Infiltrating Duct Carcinoma Breast - NOS \& its Clinicopathological Correlates, with Special Reference to Hormone Receptors
}

\author{
Authors \\ Dr Sunitha Balakrishnan ${ }^{1}$, Dr Babu K Joseph ${ }^{2}$, Dr Freena Rose ${ }^{3}$ \\ ${ }^{1}$ Associate Professor, ${ }^{3}$ Assistant Professor, Department of Pathology, Govt. Medical College, Thrissur \\ ${ }^{2}$ Assistant Professor, Department of Paediatrics, Govt. Medical College, Thrissur, Kerala \\ Corresponding Author \\ Dr Babu K Joseph \\ Assistant Professor, Department of Pediatrics, Govt. Medical College, Thrissur, Kerala, PIN -680596 \\ Phone -9446051832,0487- 2204832, Email: drbabudr@gmail.com
}

\begin{abstract}
B - cell lymphoma 2 (Bcl-2) is an antiapoptotic protein belongs to Bcl2 family. It is an important breast cancer prognostic marker. Bcl2 is upregulated by estrogen in breast cancer. Therefore, Bcl2 expression in breast cancer can be considered as a sign of estrogen functional activity.

Aim: To evaluate the expression of Bcl-2 oncoprotein in patients with infiltrating duct carcinoma, breastNOS (IDC-NOS) and to assess its correlation with various clinicopathological variables, especially hormone receptors.

Materials \& Methods: 75 cases of infiltrating duct carcinoma breast, with defined ER, PR \& Her2 status were retrieved \& immunohistochemical analysis with Bcl2 was done. Clinicopathological features were analyzed and correlation between Bcl2 expression and the above features especially hormone status were assessed.

Results \& Conclusion: 43 (57.3\%) cases of IDC - NOS showed Bcl-2 positivity. Bcl2 expression was significantly associated with lower histological grade and hormone receptor positivity. Triple negative breast carcinoma $(T N B C)$ show lack of expression of Bcl-2 in significant proportion.

Keywords: Infiltrating duct carcinoma breast, Bcl-2 Expression, hormone receptors.
\end{abstract}

\section{Introduction}

B-cell Lymphoma 2 (Bcl-2), part of the bcl-2 gene family located at chromosome $18 \mathrm{q} 21$, was first described as a result of the chromosomal translocation $\mathrm{t}(14 ; 18)^{1}$ seen in a large number of follicular B-cell lines. Bcl-2 which is an oncoprotein, suppresses programmed cell death (apoptosis) ${ }^{2}$ and is expressed in many solid tumors such as lung, colorectal, stomach and ovarian cancers. It also plays an important role in mammary epithelial differentiation and possibly in mammary neoplasia ${ }^{3}$. The mechanism by which Bcl- 2 contributes to tumorigenesis is through suppression of apoptosis, thereby conferring a survival advantage on Bcl-2 expressing cells. The prolonged life span of cells with enhanced Bcl-2 expression may contribute to the greater cellularity of proliferative lesions and increase the risk for these cells to 
acquire oncogenic genetic changes. Expression of bcl-2 has been detected in $68 \%^{4}$ and $75 \%^{5}$ of breast carcinomas in previous studies. The overexpression of $\mathrm{Bcl}-2$ in breast cancer has been found to be associated with several favorable prognostic factors such as smaller size, low cell proliferative rate $\&$ low nuclear grade ${ }^{6,7}$. The Bcl2 expression is significantly associated with the presence of estrogen (ER) and progesterone receptors $(\mathrm{PR})^{8}$. It was found that, similar to PR, the bcl-2 gene itself is ER regulated. Thus high bcl-2 may be indicative of an intact ER pathway that is driving tumor growth $\&$ should be sensitive to endocrine therapy ${ }^{9}$.

\section{Aim}

To evaluate the expression of bcl-2 oncoprotein in patients with infiltrating duct carcinoma, breast NOS (IDC-NOS) and to assess its correlation with various clinicopathological variables especially hormone receptors.

\section{Materials \& Methods}

The study was conducted in Department of Pathology, Government Medical College Thrissur. Formalin - fixed, paraffin - embedded tissue samples of 75 surgically removed IDC -NOS during the study period were taken. Only cases with immunohistochemically defined estrogen (ER) and progesterone receptor (PR) status were selected. For all cases the pathology reports regarding grade, size of the tumor, lymphnode status, presence of lymphovascular emboli \& age of the patient were available. Consecutive serial sections were cut from representative paraffin block of each case \& immunostaining were performed for Bcl-2. Positive \& negative controls were included in each run. The Bcl-2 positivity was expressed by brownish staining localized to the cytoplasm. Immunocytochemical results were scored as percentage of cells expressing definite immunoreactivity. For statistical analysis cases were considered positive for Bcl-2, if they showed immunoreactivity in more than $25 \%$ of neoplastic cells.
Statistical analysis were performed using Fisher's exact test \& Chi-square test. p- value of $<0.05$ was considered statistically significant.

\section{Result}

The various clinicopathological parameters of the 75 patients are shown in the Table 1 . Of the 75 patients included in the study, $43(57.3 \%)$ were Bcl-2 positive and $32(42.7 \%)$ were $\mathrm{Bcl}-2$ negative.

Table1-Clinicopathological parameters of 75 cases

\begin{tabular}{|c|c|c|c|}
\hline \multicolumn{2}{|l|}{ Parameter } & No & $\%$ \\
\hline \multirow[t]{2}{*}{ Age } & $<50$ & 29 & $38.7 \%$ \\
\hline & $>50$ & 46 & $61.3 \%$ \\
\hline \multirow[t]{3}{*}{ Size } & $<2 \mathrm{~cm}$ & 5 & $6.7 \%$ \\
\hline & $2-5 \mathrm{~cm}$ & 58 & $77.3 \%$ \\
\hline & $>5 \mathrm{~cm}$ & 12 & $16.0 \%$ \\
\hline \multirow[t]{3}{*}{ Grade } & 1 & 4 & $5.3 \%$ \\
\hline & 2 & 58 & $77.3 \%$ \\
\hline & 3 & 13 & $17.3 \%$ \\
\hline \multirow[t]{2}{*}{ In-situ component } & Positive & 22 & $29.3 \%$ \\
\hline & Negative & 53 & $70.7 \%$ \\
\hline \multirow[t]{2}{*}{ LVE } & Positive & 23 & $30.7 \%$ \\
\hline & Negative & 52 & $69.3 \%$ \\
\hline \multirow[t]{2}{*}{ Lymphnode } & Positive & 41 & $54.7 \%$ \\
\hline & Negative & 34 & $45.3 \%$ \\
\hline \multirow[t]{2}{*}{ ER } & Positive & 51 & $68.0 \%$ \\
\hline & Negative & 24 & $32.0 \%$ \\
\hline \multirow[t]{2}{*}{ PR } & Positive & 39 & $52 \% \%$ \\
\hline & Negative & 36 & $48 \%$ \\
\hline \multirow[t]{2}{*}{ HER2 } & Positive & 26 & $34.6 \%$ \\
\hline & Negative & 49 & $65.3 \%$ \\
\hline \multirow[t]{2}{*}{ TNBC } & Yes & 15 & $20.0 \%$ \\
\hline & $\mathrm{No}$ & 60 & $80.0 \%$ \\
\hline \multirow[t]{2}{*}{ Bcl-2 } & Positive & 43 & $57.3 \%$ \\
\hline & Negative & 32 & $42.7 \%$ \\
\hline
\end{tabular}

The clinicopathological characteristic according to $\mathrm{Bcl} 2$ expression are summarized in Table 2. Bcl2 -positive expression was associated with low histological grade $(\mathrm{p}<0.003)$, ER \& PR positivity $(p<0.001)$. Triple negative breast carcinomas (TNBC) ie, ER, PR \& Her-2 negative breast carcinomas show lack of expression of Bcl-2 ( $\mathrm{p}$ $<0.001$ ). The parameters like tumor size, in - situ components, lymphnode status and lymphovascular emboli show no statistically significant association with bcl2 expression. In patients lacking $\mathrm{Bcl} 2$ expression majority were with age $>50$ years $(71.9 \%)$, as compared to patients with < 50 years $(28.1 \%)$, even though the relation was not statistically significant. Majority of $\mathrm{Bcl} 2$ positive cases (72.1\%) lack expression of HER 2. 
Table 2 -Clinicopathological characteristics according to $\mathrm{Bcl} 2$ expression $(\mathrm{n}=75)$

\begin{tabular}{|c|c|c|c|c|}
\hline \multicolumn{2}{|c|}{ Characteristic } & \multirow{2}{*}{$\begin{array}{c}\begin{array}{c}\text { Bcl-2 +ve } \\
(\mathrm{n}=43)\end{array} \\
20 \\
(46.5 \%)\end{array}$} & \multirow{2}{*}{$\begin{array}{c}\begin{array}{c}\text { Bcl-2 } \\
\text {-ve } \\
(\mathrm{n}=32)\end{array} \\
9 \\
(28.1 \%)\end{array}$} & \multirow{3}{*}{$\begin{array}{c}\text { p- value } \\
0.106\end{array}$} \\
\hline \multirow[t]{2}{*}{ Age } & $<50$ & & & \\
\hline & $>50$ & $\begin{array}{c}23 \\
(53.5 \%)\end{array}$ & $\begin{array}{c}23 \\
(71.9 \%)\end{array}$ & \\
\hline \multirow[t]{3}{*}{ Size } & $<2 \mathrm{~cm}$ & $4(9.3 \%)$ & $1(3.1 \%)$ & \multirow[t]{3}{*}{0.517} \\
\hline & $2-5 \mathrm{~cm}$ & $\begin{array}{c}33 \\
(76.7 \%) \\
\end{array}$ & $\begin{array}{c}25 \\
(78.1 \%) \\
\end{array}$ & \\
\hline & $>5 \mathrm{~cm}$ & $\begin{array}{c}6 \\
(14 \%) \\
\end{array}$ & $\begin{array}{c}6 \\
(18.8 \%) \\
\end{array}$ & \\
\hline \multirow[t]{3}{*}{ Grade } & 1 & $3(7 \%)$ & $1(3.1 \%)$ & \multirow[t]{3}{*}{0.003} \\
\hline & 2 & $\begin{array}{c}38 \\
(88.4 \%) \\
\end{array}$ & $\begin{array}{c}20 \\
(62.5 \%) \\
\end{array}$ & \\
\hline & 3 & $2(4.7 \%)$ & $11(34.4 \%)$ & \\
\hline \multirow{2}{*}{$\begin{array}{l}\text { In-situ } \\
\text { componen } \\
\mathrm{t}\end{array}$} & $+\mathrm{ve}$ & $\begin{array}{c}12 \\
(27.9 \%)\end{array}$ & $\begin{array}{c}10 \\
(31.3 \%)\end{array}$ & \multirow[t]{2}{*}{0.753} \\
\hline & -ve & $\begin{array}{c}31 \\
(72.1 \%) \\
\end{array}$ & $\begin{array}{c}22 \\
(68.8 \%)\end{array}$ & \\
\hline \multirow[t]{2}{*}{ LVE } & $+\mathrm{ve}$ & $12(27.9 \%)$ & $11(34.4 \%)$ & \multirow[t]{2}{*}{0.548} \\
\hline & -ve & $\begin{array}{c}31 \\
(72.1 \%) \\
\end{array}$ & $\begin{array}{c}21 \\
(65.6 \%) \\
\end{array}$ & \\
\hline \multirow[t]{2}{*}{$\begin{array}{l}\text { Lymph } \\
\text { node }\end{array}$} & $+\mathrm{ve}$ & $\begin{array}{c}24 \\
(55.8 \%) \\
\end{array}$ & $\begin{array}{c}17 \\
(53.1 \%) \\
\end{array}$ & \multirow[t]{2}{*}{0.817} \\
\hline & -ve & $\begin{array}{c}19 \\
(44.2 \%) \\
\end{array}$ & $\begin{array}{c}15 \\
(46.9 \%)\end{array}$ & \\
\hline \multirow[t]{2}{*}{ ER } & + ve & $\begin{array}{c}38 \\
(88.4 \%) \\
\end{array}$ & $\begin{array}{c}13 \\
(40.6 \%) \\
\end{array}$ & \multirow[t]{2}{*}{$<0.001$} \\
\hline & -ve & $\begin{array}{c}5 \\
(11.6 \%) \\
\end{array}$ & $\begin{array}{c}19 \\
(59.4 \%)\end{array}$ & \\
\hline \multirow[t]{2}{*}{ PR } & $+\mathrm{ve}$ & $\begin{array}{c}31 \\
(72.1 \%)\end{array}$ & $\begin{array}{c}8 \\
(25 \%)\end{array}$ & \multirow[t]{2}{*}{$<0.001$} \\
\hline & -ve & $\begin{array}{c}12 \\
(27.9 \%)\end{array}$ & $\begin{array}{c}24 \\
(75 \%)\end{array}$ & \\
\hline \multirow[t]{2}{*}{ HER2 } & $+\mathrm{ve}$ & $\begin{array}{c}12 \\
(27.9 \%)\end{array}$ & $\begin{array}{c}14 \\
(43.7 \%) \\
\end{array}$ & \multirow[t]{2}{*}{0.154} \\
\hline & -ve & $\begin{array}{c}31 \\
(72.1 \%)\end{array}$ & $\begin{array}{c}18 \\
(6.2 \%)\end{array}$ & \\
\hline \multirow[t]{2}{*}{ TNBC } & Yes & $\begin{array}{c}2 \\
(4.7 \%)\end{array}$ & $\begin{array}{c}13 \\
(40.6 \%)\end{array}$ & \multirow[t]{2}{*}{$<0.001$} \\
\hline & No & $\begin{array}{c}41 \\
(95.3 \%)\end{array}$ & $\begin{array}{c}19 \\
(59.4 \%)\end{array}$ & \\
\hline
\end{tabular}

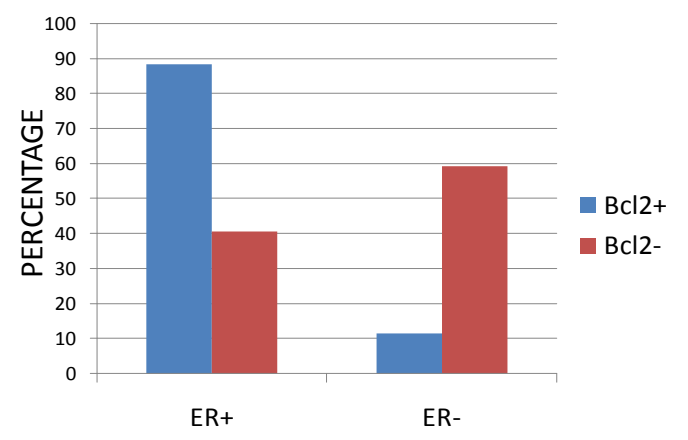

Figure 1: Bar chart showing relationship between expressions of Bcl-2 \& ER

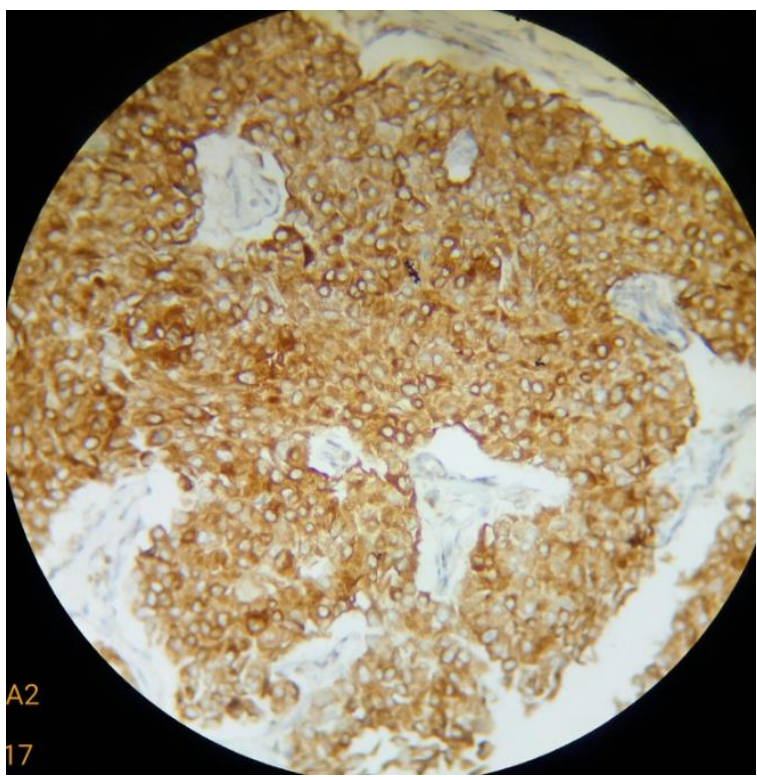

Figure 2: Bcl-2 positivity in tumor cells

\section{Discussion}

$\mathrm{Bcl} 2$ expression is associated with a favorable prognosis in many solid tumors including breast cancer. The mechanism of BCL2 as a prognostic factor in breast cancer remains unclear. Many studies have suggested that interactions between BCL2 and ER modulate the prognostic effect ${ }^{10}$. Moreover, BCL2 expression is upregulated in response to estrogens, and so BCL2 is considered an estrogen-related protein ${ }^{10}$.

In the present study, BCL2 was expressed in $57.3 \%$ of IDC- NOS, which is similar to previous studies ${ }^{11}$. Most investigators reported that $\mathrm{Bcl}-2$ immunoreactivity was more frequent in low-grade carcinomas $^{4,5}$, similar to our study results. Lymphnode status which is the most powerful predictor of clinical outcome shows no significant relation with Bcl-2 in present study. As for the nodal status ,data are very heterogenous . Callagy et al found no correlation and supports our findings ${ }^{12}$. However, Chen et $\mathrm{al}^{13}$ in a study done on 74 cases of breast cancer found, Bcl-2 imunoreactivity to be significantly correlated with negative lymphnode and in cases with less nodal involvement. Age of the patient, tumor size, presence of in-situ component and lymphovascular emboli show no significant correlation with Bcl-2 expression. 
The expression of bcl-2 and the expression of ER and PR were highly associated in this study, which is in agreement with previously published data by Le M G et al and Callagy ${ }^{14,15}$.These observations support the hypothesis that bcl-2 expression in breast carcinoma may be an estrogen receptor regulated phenomenon and PR is under estrogen regulation via $\mathrm{ER}^{16}$.

Some investigators reported an inverse relationship between Bcl-2 expression and the immunohistochemical detection of HER $2^{17}$. Even though statistically not significant, present study also supports this finding as majority of $\mathrm{Bcl} 2$ positive cases $(72.1 \%)$ lack expression of Her 2 .

The present study of $\mathrm{Bcl}-2$ expression in breast cancer by means of immunohistochemistry shows that in spite of its role opposing tumor cell death, Bcl-2 is associated with better intrinsic prognostic biological features such as hormone receptor expression and lower histological grade. This may in great part explain why Bcl-2 expression has been invariably found to correlate with a better prognosis of breast cancer ${ }^{11,18}$.

The identification of prognostic and predictive markers is clinically important, because breast cancer is heterogenous in respect to genetics, and variable in biological and clinical features. At present, gene expression microarray studies have shown prognostic power, but IHC remains a suitable and powerful method of prognostication in a clinical situation because it is less expensive and more easily applied in clinical context

\section{Conclusion}

The present study observes that BCL2 expression is significantly associated with lower grade and ER and PR positivity; therefore, BCL2 expression can be used for predicting an overall good prognosis in patients with breast cancer. Evaluation of $\mathrm{Bcl} 2$ expression in breast cancer may identify a subset of patients with favorable prognosis, who may not benefit from chemotherapy but may benefit from Bcl-2 targeting agents in addition to antihormonal therapy.

\section{References}

1. Tsujimoto, y.\& Gorham, j., Cossman, j.,Jaffe, e. \& Croce, c.m. (1985). The t (14; 18) chromosome translocations involved in B-cell neoplasms result from mistakes in VDJ joining. Science, 299, 1390-1393.

2. Hockenbery, d., Nunez, g., Milliman, c., Schreiber, r.d. \& Korsmeyer, s.j. (1990). Bcl-2 is an inner mitochondrial membrane protein that blocks programmed cell death. Nature, 348, 334-336.

3. Bargou RC, Daniel PT, Mapara MY, et al. Expression of the bcl-2 gene family in normal and malignant breast tissue: low bax-(alpha) expression in tumor cells correlates with resistance towards apoptosis. Int J Cancer 1995;60:854-859.

4. Visscher DW, Sarkar F, Tabaczka P, et al Clinicopathologic analysis of bcl-2 immunostaining in breast carcinoma. Mod Pathol 1996;9:642-646.

5. Hellemans P, van Dam PA, Weyler J, et al. Prognostic value ofbcl-2 expression in invasive breast cancer. $\mathrm{Br} J$ Cancer 1995;72:354-360.

6. Bozzetti C, Nizzoli R, Naldi N, et al. Bcl2 expression on fine needle aspirates from primary breast carcinoma - Correlation with other biological factors . Ca. Cytopathol. 1999;87(4):224-230

7. Hun Lee K, Ah Im S, Youn Oh D, et al. Prognostic significance of Bcl-2 expression in stage III breast cancer patients who had received doxorubicin and cyclophosphamide followed by paclitaxel as adjuvant chemotherapy. BMC Cancer 2007: 7; 63-70

8. Bhargava V, Kell DL, van de Rijn M, et al. Bcl-2 immunoreactivity in breast carcinoma correlates with hormone receptor positivity. Am J Pathol1994;145:535-540.

9. Linke S P, Bremer T M , Herold C D et al. A multimarker model to predict outcome in tamoxifen treated breast cancer patients . Clin Ca. Res 2006;15:1175-1183 
10. Park SH, Kim H, Song BJ. Down regulation of bcl2 expression in invasive ductal carcinomas is both estrogen- and progesterone-receptor dependent and associated with poor prognostic factors. Pathol Oncol Res 2002;8:26-30.

11. Seong MK, Lee JY, Byeon J, Sohn YJ, Seol H, Lee JK, et al. Bcl-2 is a highly significant prognostic marker of hormonereceptor-positive, human epidermal growth factor receptor-2-negative breast cancer. Breast Cancer Res Treat 2015;150:141-8.

12. Callagy GM, Pharoah PD, Pinder SE, Hsu FD, Nielsen TO, Ragaz J, et al. Bcl-2 is a prognostic marker in breast cancer independently of the Nottingham Prognostic Index. Clin Cancer Res 2006;12:2468-75.

13. Chen H.W.,su W.C., Guo h. et al. p53 and c-erbB-2 but not bcl-2 are predictive of metastasis free survival in breast cancer patients receiving post-mastectomy adjuvant radiotherapy in Taiwan. Japan. J. Clin. Oncol. 2002;32:332-339

14. Callagy GM, Webber MJ, Pharoah PD, Caldas C. Met-analysis confirm BCL2 is an independent prognostic marker in breast cancer. BMC Cancer. 2008;8:153

15. Le MG, Mathieu M-C, Douc-Rasy S, et al. c-myc, p53 and bcl-2, Apoptosis-related genes in infiltrating breast carcinomas: Evidence of a link between bcl-2 protein over-expression and a lower risk of metastasis and death in operable patients. Int J Cancer. 1999;84:562-7.

16. Gee JM, Robertson JRR, Ellis IO. Immunocytochemical localization of Bcl-2 protien in human breast cancers and its relationship to a series of prognostic markers and response to endocrine therapy. Int J Cancer. 2006;5:619-28.

17. Leek RD, Kaldam.anis L, Pezzella F, et al. bcl-2 in normal human breast and carcinoma, association with oestrogen receptor-positive, epidermal growth factor receptor-negative tumours and in situ cancer. Br J Cancer 1994;69:135-139.

18. Chen LY, Tsang JY, Ni YB, Chan SK, Chan KF, Zhang s,et al. Bcl2 and ki 67 refine prognostication in luminal breast cancers. Breast Cancer Res Treat2015; 149:631-43 